\title{
Correction to: Factors affecting the cost of managed aquifer recharge (MAR) schemes
}

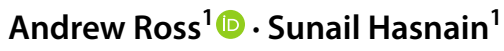

Published online: 5 June 2018

(c) Springer International Publishing AG, part of Springer Nature 2018

\section{Correction to: Sustainable Water Resources Management https://doi.org/10.1007/s40899-017-0210-8}

The original version of this article unfortunately contained mistakes.

One MAR scheme, 12-SAT-AS, should be classified as using infiltration basins rather than recharge wells. This revised classification requires the following corrections:

Table 1 Column 4 Reclassify Scheme 12 SAT-AU-AUS as infiltration/spreading basins.

Page 8 Overview of costs of MAR schemes by MAR type. In paragraph 2 delete the sentences $1-3$ and replace by "The data presented in Table 6 show that schemes using natural water have much lower costs than schemes using recycled water, and infiltration/spreading basins using natural water have the lowest recharge costs".

Page 8 Infiltration and spreading basins (source recycled water). Revise sentence 3 to read "In this study, this is the category with the highest average unit costs for recharging water, related to the cost of land, level of treatment or conservative assumptions about the need to periodically reform basins. Delete sentence 4 "Operating costs are lower... with recycled water".

Table 6 Results in the first two rows of the table should read as follows:

\begin{tabular}{llll}
\hline & $\begin{array}{l}\text { Capital cost/ } \\
\mathrm{m}^{3} \text { recharged }\end{array}$ & $\begin{array}{l}\text { O\&M cost } / \mathrm{m}^{3} \\
\text { recharged }\end{array}$ & $\begin{array}{l}\text { Levelised } \\
\text { cost }\left(\mathrm{US} \$ \mathrm{~m}^{3}\right. \\
\text { recharged) }\end{array}$ \\
\hline $\begin{array}{c}\text { Recharge wells/ } \\
\text { recycled water } \\
\text { (four schemes) }\end{array}$ & $\$ 8.07$ & $\$ 0.53$ & $\$ 1.16$ \\
$\begin{array}{c}\text { Infiltration basins/ } \\
\text { recycled water } \\
\text { (three schemes) }\end{array}$ & $\$ 11.41$ & $\$ 0.84$ & $\$ 1.89$ \\
\hline
\end{tabular}

The original article can be found online at https://doi.org/10.1007/ s40899-017-0210-8.

Andrew Ross

a.ross@anu.edu.au

1 Australian National University, Canberra, Australia 